\title{
The Passion of The LoRd Jesus Christ in Early Christian Confessions
}

DOI: $10.14232 /$ jp.pgy.2021.2

The purpose of this short paper is in part to give a comparative presentation of the sufferings of Lord Jesus Christ in the Western Creeds, and we also try to define the role of mentioning the name of Pontius Pilatus in them. The reason for doing so is that these passages are frequently the source of theological misunderstandings and debates. Furthermore, it is important to know that this paper is an expanded and somewhat more elaborate version of an earlier study in which I tried to give a general overview on the word-usage concerning the passion of Jesus Christ in the early Christian creeds. ${ }^{288}$ Back then, I used the excellent collection of August Hahn as primary source, ${ }^{289}$ but without a text-historical analysis. Now, I will limit the presentation to the creeds of western Christianity from the late antiquity and early Middle Ages (mostly the creeds from the families of R and T), ${ }^{290}$ but - where I see it necessary - I will refer to eastern creeds as well. In the present study, I used the very comprehensive work of Liuwe Westra ${ }^{291}$ as the most important source for the text-reconstructions of the creeds. In order to preserve the perspicuity of our study, first, we will present the biblical background of the question, then there follows a selection from the works of the earliest Christian writers about the passion of Jesus Christ. Thereafter, I will present an analysis of the corresponding articles of $\mathrm{R}$, then of its daughter-creeds in a regional arrangement. Finally, in a brief excursus, I will present the formulation of the passion of Lord Jesus Christ in the creeds of the Oriental Churches (including the ecumenical councils) and I will try to formulate the conclusions.

The main question which urged me to do this research had occurred in connection with the Apostolic Creed ${ }^{292}$, namely, which version is correct:

288 Papp György: The Passion of the Lord Jesus Christ in Early Christian Confessions, in: Református Szemle (Reformed Review), Cluj-Napoca 2008/6. 700-708.

289 Hahn, August (ed.): Bibliothek der Symbole und Glaubensregeln der Alten Kirche. Verlag von E. Morgenstern, Breslau 1897 (hereafter Hahn: Bibliothek der Symbole. Verlag von E. Morgenstern, Breslau 1897.).

290 R denotes the Creeds from the family of the Old Roman Creed, while $\mathrm{T}$ the textus receptus of the Apostle's Creed.

291 Westra, Liuwe: The Apostles' Creed. Origin, History, and Some Early Commentaries. Brepols, Turnhout 2002. (hereafter Westra, Liuwe: The Apostles'Creed. Brepols, Turnhout 2002.)

292 Here we must note that the Apostolic Creed is apostolic only concerning its teaching, and not its authorship. 
- "I believe in Jesus Christ, His only Son, our Lord: Who was conceived of the Holy Spirit, born of the Virgin Mary, suffered under Pontius Pilate, was crucified, died, and was buried; He descended into hell..."

or

- "I believe in Jesus Christ, His only Son, our Lord: Who was conceived of the Holy Spirit, born of the Virgin Mary, suffered, under Pontius Pilate He was crucified, died, and was buried; He descended into hell..."?

I shall try to answer this question by analysing the relevant passages of the creeds which were composed in the first eight centuries.

\section{"YOU HAVE REDEEMED US THROUGH MANY PASSIONS..." (JaN HuS) - BIBLICAL INTRODUCTION ${ }^{293}$}

'The Messiah of God was behoving to suffer all these things, and to enter into his glory' (Luke 24,26) - this is the core of the teaching that even the disciples did not understand. They were waiting for the Messiah who would redeem Israel, and somebody came from Nazareth, who was a mighty prophet in deed and word in front of God and all the people (Luke 24,19), but in the end it turned out that he was totally different from the Messiah they had been waiting for. They were hoping that he would be the

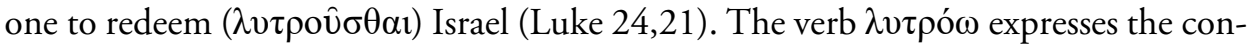
cept of 'setting free' by paying a ransom. The Messiah-expectations interpreted this expression suggesting that once God's Messiah arrives, he will deliver Israel from under the rule of its current enemy - in this case from under the Roman oppression. The strong political connotation of this Messiah-image manifests after the feeding of the five thousand, when the crowd wanted to proclaim Jesus their king (John 6,14-15). Yet He was not a political Messiah, and His duty was not the origination and establishment of political independence but He was the one who was to save ( $\sigma \dot{\sigma} \sigma \varepsilon l)$ his people from their sins (Matthew 1,21). This way, it was declared before his birth that He will not mend the relationship between Romans and Jews but rather the one between God and humankind. This is why it was his duty to suffer and die, since - according to the Torah - there is no remission without bloodshed (Hebrews 9,22). He foretold his future passions his disciples (Mt 16,21; 20,14; Mk 10,32); after His resurrection, $\mathrm{He}$ explained their meaning on the way to Emmaus, and He has been proclaiming the same message for the past two millennia.

The prophets had spoken and written about His passion, and He revealed that to the two disciples, 'beginning at Moses and all the prophets, he expounded unto them in all the scriptures the things concerning himself (Luke 24,27). The most important prophecies 
concerning the passion of our Lord are undeniably the prophecies of Isaiah about the Suffering servant of God (especially Is 50,6; Is 52,13-53,12). Likewise, in the passion of Christ, the prophecies of Psalm 22 are fulfilled. ${ }^{294}$ According to Isaiah, the passion of the Suffering Servant is undoubtedly a 'locum-tenens' sacrifice: "Surely he hath borne our grieves, and carried our sorrows: yet we did esteem him stricken, smitten of God, and afflicted. But he was wounded for our transgressions, he was bruised for our iniquities: the chastisement of our peace was upon him; and with his stripes we are healed. All we like sheep have gone astray; we have turned every one to his own way; and the LORD hath laid on him the iniquity of us all" (Is 53,4-6).

The canonical books written after the resurrection of the Lord speak about His passion as the fulfilment of the prophecies of the Old Testament. The three decades between the events and their conception ${ }^{295}$ did not becloud the events, what is more, Paul the Apostle wrote to the Galatians after many years: "before your eyes Jesus Christ hath been evidently set forth, crucified among you" (Gal 3,1). The Gospels and the apostolic Epistles set forth the events of Jesus's life as historical facts, signifying that they preach the might and the Second Advent not by following some cunningly devised fables

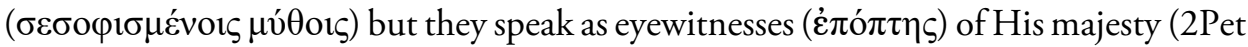
1,16). This claim of authenticity is confirmed by the fact that during the time of the Gospels' composition, the eyewitnesses of His life, including the people healed by Him, were still alive. ${ }^{296}$ Based on the biblical testimony, we cannot agree with those exegetes who claim that the redeeming death of the Lord and His resurrection was merely a later interpretation of the disciples, an interpretation triggered by the psychological effects of Jesus's teaching. ${ }^{297}$

The writers of the New Testament emphasise that Jesus's death was not a simple death but rather a redeeming death. The purpose and result of His passions and death are set forth by them in plastic and dynamic images in the Church: "knowing that ye were redeemed, not with corruptible things, with silver or gold, from your vain manner of life handed down from your fathers; but with precious blood, as of a lamb without spot, even

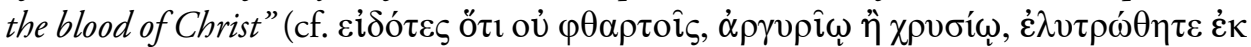

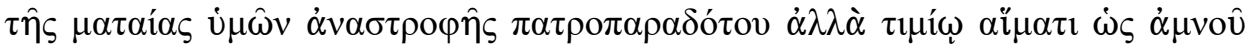

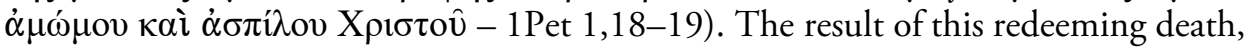

294 In patristic literature, but not only there, Psalm 22 is interpreted as a Christological prophecy about the Messiah's passion.

295 Concerning the dating of New Testament books I follow here the thesis of Carsten Peter Thiede and J. A. T. Robinson, who claim that the whole New Testament was complete until the year 70. See J. A. T. Robinson, Redating the New Testament, London, SCM Press LTD, 1976; Carsten Peter Thiede, Eyewitness to Jesus, Doubleday, 1996. (in Hungarian: Aki látta Jézust, Debrecen, Goldbook, sine anno).

296 Carsten Peter Thiede, Aki látta Jézust, Debrecen, Goldbook, é.n, 16. (Eyewitness to Jesus, Hungarian edition)

297 Cf. Geréb Pál, Barth Károly Dogmatikája, Kolozsvár, Erdélyi Református Egyházkerület, 2006, 527. (Geréb Pál, A compendium of Karl Barth's Dogmatics, Hungarian edition) 
of this sacrifice for our sins (i $\lambda \alpha \sigma \tau \eta \dot{\rho} \rho ı v)$ is redemption, liberation ( $\left.\dot{\alpha} \pi \circ \lambda v_{\tau} \rho \omega \sigma \iota \varsigma\right)$,

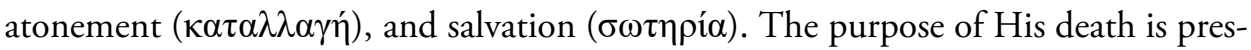
ented in the clearest possible way in the Epistle of Paul to the Romans: "so then as through one's trespass the judgment came unto all men to condemnation; even so through one's act of righteousness the free gift came unto all men to justification of life" (Rom 5,18).

Upon reading these notes, we might ask: when did the redeeming passions of our Lord truly begin? In the Garden of Gethsemane, where He was sweating blood? The New Testament teaches us that the Passion of the Lord did not begin with the events preceding Good Friday but with His birth, when He emptied himself, taking the form of a servant, being made in the likeness of men (Phil 2,7). The great Hungarian bishop of the $20^{\text {th }}$ century László Ravasz writes about the passion of the Lord the following way:

The passion of Christ is a grandiose crescendo, which began with His birth and continued until His death. Here we can speak about His poverty, homelessness, solitude. We must mention here that his own people despise Him and give Him over to death. And here belongs his gradual abandonment [by His own disciples] and His pain on account of the destructive effect of sin. That people did not receive His Gospel. 'But you would not' (cf. Luke 13,34). The events in the Garden of Gethsemane are the pinnacle of this passion, when His most faithful disciples fell asleep while He, sweating blood, implored His Father: 'Father, if is it possible...' [...] His death is the essence, the multiplication of His sufferings. Let us observe the disgracefulness of this death... ${ }^{298}$

So, the Passion of our Lord began with His incarnation ( $\dot{\varepsilon} v \alpha v \theta \rho \omega ́ \pi \eta \sigma ા \zeta)$ which is called self-humiliation by the apostle Paul, or self-emptying (exinanitio, $\kappa \dot{\varepsilon} v \omega \sigma ı \varsigma$, in the patristic literature: $\tau \alpha \pi \varepsilon i v \omega \sigma i \varsigma)$. The $37^{\text {th }}$ answer of the Heidelberg Catechism reflects on the same question and confirms this interpretation:

What do you understand by the word "suffered"?

That during his whole life on earth, but especially at the end, Christ sustained in body and soul the anger of God against the sin of the whole human race. This he did in order that, by his suffering as the only atoning sacrifice, he might set us free, body and soul, from eternal condemnation, and gain for us God's grace, righteousness, and eternal life.

\section{TO KNOW ONLY ABOUT THE CRUCIFIED LORD (ICOR 2,2)}

While the apostle decided to have knowledge of nothing among the Corinthians, but only of Jesus Christ on the cross (1Cor 2,2), no confession can avoid the testimony of redeeming passion and death of our Lord Jesus Christ.

298 Ravasz László, Kis dogmatika, Budapest, Kálvin Kiadó, 1996, 92-93. (László Ravasz, Little Dogmatics, Hungarian edition) 
History reveals that the earliest Creeds, some of which we can also read in the Bible, were very short and concise, expressing only a few aspects of faith. For example, when somebody says, 'I believe that Jesus is the Christ, the Son of God' (John 11,27; Mt 16,18; Acts 8,37), they answer the question: who is Jesus in his person (persona Christi cognoscere)? Yet the statement 'I believe that Jesus Christ, the Son of God is our Saviour' is the answer to the following question: what did Jesus do, and who is He in His acts (beneficia Christi cognoscere)? Later, during the time of great theological debates when newer problematic questions came forth, detailed creeds were formulated which sketched out the teaching about salvation, detailing each article. Hereinafter, I shall present the parts of the Christological passages from the earliest creeds that discuss the passion of our Lord in some detail. ${ }^{299}$

We find one of the earliest credal formulas - following the apostolic age - in the letters of Ignatius of Antioch: ${ }^{300}$

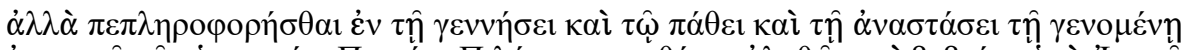

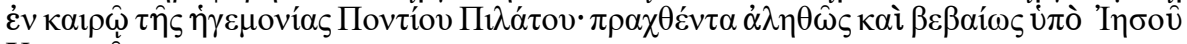

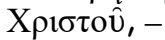

[...] but may be fully persuaded of the birth, the passion, and the resurrection which happened in the time of the governorship of Pontius Pilate, which things were truly and surely done by Jesus Christ (Magnes 11).

The first particularity we observe is that in this fragment with the name of Pontius Pilate, Ignatius does not define the date of the crucifixion but rather the resurrection of the Lord Jesus Christ, apparently because he wanted to demonstrate that the resurrection of the crucified Lord was a real and historical fact. He did not enclose the Lord's passion into a specific time-frame, and that suggests that he saw the Passion as a chain of events which began with the birth of Jesus Christ. The same idea can be seen in the Epistle to the Ephesians:

For our God, Jesus the Christ, was conceived in the womb by Mary according to the dispensation, of the seed of David but also of the Holy Ghost; and He was born and was baptized that by His passion He might cleanse water (Eph 18,2).

In the Epistle to the Trallians we observe that Ignatius, whilst describing the events endured by Jesus Christ under Pontius Pilate, does not use the verb $\pi \alpha \dot{\sigma} \alpha \omega$, but the

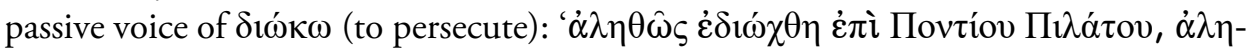

299 For the original text of the Creeds discussed here see August Hahn (ed.), Bibliothek der Symbole und Glaubensregeln der Alten Kirche, Breslau, Verlag von E. Morgenstern, 1897 (hereafter Hahn, Bibliothek der Symbole).

300 Ignatius of Antioch died as a martyr (in $110 \mathrm{AD}$ ) under the reign of Emperor Traianus (98-117 $\mathrm{AD}$ ) in the Colosseum. He wrote six letters to the following congregations: Magnesia, Tralles, Ephesus, Rome, Philadelphia and Smyrna; and one to the bishop of Smyrna, Polycarp. 


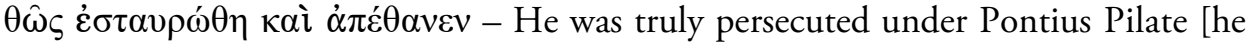
was] truly crucified and died' (Trall 9). In the epistle to the Smyrnaeans, we read: ' $\alpha \lambda \eta$ -

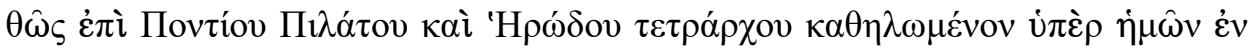
баркí - in the time of Pontius Pilate and Herod, the tetrarch, he was truly nailed [to the cross] for us in the flesh' (Smyrn 1,2; see also in Ignatius, Smyrn 1,1; Barnabas V 13.). ${ }^{301}$

In his writings, Justin Martyr ${ }^{302}$ uses the verb $\sigma \tau \alpha$ pó $\omega$ (= crucify) to denote the

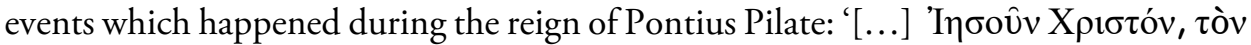

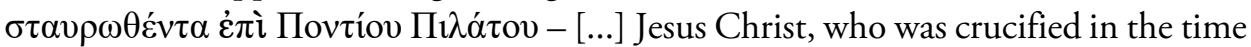
of Pontius Pilate' (First Apology 13; 61). In his Dialogue with Trypho, Justin distinguishes the passion of the Lord Jesus Christ from the crucifixion which he endured under Pontius Pilate:

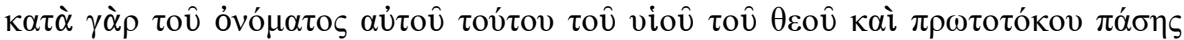

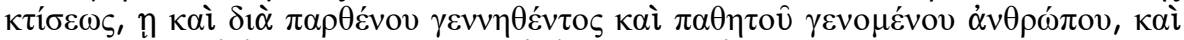

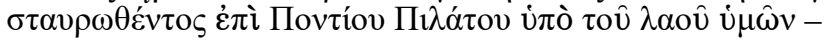

... for against the name of this same Son of God and Firstborn of the whole creation, who became man by the Virgin, who suffered, and was crucified under Pontius Pilate by your nation ${ }^{303} \ldots$... (Trypho 85 ).

We can see that in this fragment, the verb $\pi \alpha \sigma \chi \omega$ refers to the whole life of Jesus, and

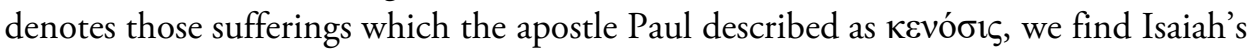
prophecy in the background of this usage, according to which the Messiah who will deliver his own nation from their sins will be 'a man of sorrows and familiar with suffering' (Is 53,3).

The next important stage in our research concerning the early creeds about the Suffering Messiah is represented by the work Adversus haereses of Irenaeus of Lyons (the name of Lyon was Lugdunum in the antiquity), who died around the year 202. In the Latin version of this originally Greek work, we encounter the expression passus sub Pontio Pilato (Adv haer III. 4,2) for the first time. In the $16^{\text {th }}$ chapter of the same work, he uses the verb patior without setting a date:

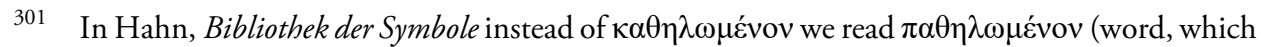
does not occur in the dictionaries). This is probably the result of a typographical error. The right among others could be found in Kirsopp Lake (ed.), The Apostolic Fathers, http://www.ccel.org/ccel/ lake/fathers2.html (opened at 20. February 2007.).

302 Justin, venerated as martyr and philosopher died around 165 in Rome. His most important writings are the two Apologies, and the Dialogue with Trypho.

303 I mention only as a matter of curiosity that the term 'nation' is expressed by the word $\lambda \alpha$ ó $\varsigma$, which denotes the elected Israel in the usage of the Septuagint and of the New Testament. With its application here the author accentuates that Jesus was rejected by his own nation. 
Non ergo alterum filium hominis novit evangelium nisi hunc, qui ex Maria, qui et passus est - The Gospel, therefore, knew no other son of man but Him who was of Mary, who also suffered; and no Christ who flew away from Jesus before the passion; but Him who was born it knew as Jesus Christ the Son of God, and that the same suffered and rose again (Adv haer III. 16,5).

With the expression 'passus est', Irenaeus seems to refer to the sufferings endured in the time of Pontius Pilate. This usage differs from that of the aforementioned authors, since he notes the events of Good Friday with the verb $\pi$ ó $\sigma \chi \omega-$ patior, which had a rather general meaning in the previous tradition. It probably would have been more appropriate to use more specific and accepted verbs like $\sigma \tau \alpha v \rho o ́ \omega-$ crucifigo, or $\delta เ \hat{\kappa} \kappa \omega-$ persequor, or even crucio (= to inflict torture upon, to torment, to rack) ${ }^{304}$ when referring specifically to the events of Good Friday.

In North-Africa, Tertullian (he died around 220), who was the younger contemporary of Irenaeus, noted the suffering of the Lord under Pontius Pilate with the words mentioned below:

Credendi [...] et filium ejus Jesum Christum, natum ex virgine Maria, crucifixum sub Pontio Pilato - to believe in His Son, Jesus Christ, who was born by the virgin Mary, and under Pontius Pilate he was crucified" (De virgin vel 1).

Furthermore, in his work Adversus Praxeam, whilst speaking of the 'passion' of the Lord which could be a reference to His whole human life as well as to His sufferings under Pontius Pilatus, Tertullian uses the verb 'patior':

Hunc missum a patre in virginem ex ea natum, hominem et deum, filium hominis et filium dei, et cognominatum Jesum Christum; hunc passum, hunc mortuum et sepultum, secundum scripturas... - He was sent by the Father into the Virgin, He was born from $\mathrm{Her}, \mathrm{He}$ is man and God, son of man and Son of God, the above-named Jesus Christ. He suffered and died, [after that] He was buried according to the Scriptures" (Adv Praxeam 2).

In the first book of his De principiis, Origen uses the verb patior in the same sense, although he accentuates the fact that the passion of the Lord was real, not an illusion or phantasy: '[...] passus est in veritate, et non per phantasiam - He suffered truly, and not by appearance" (De principiis I, Praefatio, 4).

Speaking of the final passion of the Lord in the creeds of Adamantius and Alexander of Alexandria ${ }^{305}$, we find the verb $\sigma \tau \alpha v \rho o ́ \omega:$

304 For the meanings of the verb crucio see Oxford Latin Dictionary, Oxford, Clarendon Press, 1968, 461.

305 Alexander of Antioch died around the year 326, during the outbreak of the Arian controversy after Nicaea. Nonetheless, at a local council held in 317 he rejected the heresy of Arius for the first time. 


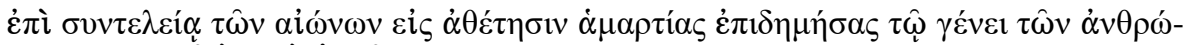

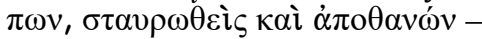

in the fullness of times He arrived to the human race in order to abolish sin, He was crucified, and died..." (from the creed of Alexander of Alexandria). ${ }^{306}$

\section{The R / Proto-R CONCERNING THE REDEMPTIVE PASSION OF THE LORD JESUS CHRIST}

According to the concurrent opinion of the scientific research, the most likely predecessor of the Apostles' Creed is the Old Roman (Baptismal) Creed. The very first evidence could be found in the Commentarius in symbolum apostolorum of Rufinus of Aquileia, written in ca. 404. However, it is obvious that Rufinus quoted a much earlier text in the above-mentioned work. According to Kelly, the history of R goes back to "the obscurity of the second century" ${ }^{307}$ when both Greek and Latin were used as liturgical languages in Rome, but we cannot ignore the fact that some of its Christological elements were composed at the beginning of the second century, in the time of Justinus, and that the semi-stereotyped proclamation of the good news about Christ was inherited practically unaltered from the Apostles. ${ }^{308}$

In opposition, Westra is more cautious when he speaks about the origins of R. He marks with $\mathrm{R}$ the form of the Creed which was applied in the $4^{\text {th }}$ century in Rome, and the original form of it, the "hypothetical father of all extant variants of the Apostles' Creed", which he supposed to have been composed before 250, he denotes as ProtoR. ${ }^{309}$ Three differences are worth to be noted between the two texts: ${ }^{310}$ the Proto- $\mathrm{R}$ omits "unicum dominum nostrum" from the second article ${ }^{311}$, the expression "a mortuis" from the sixth article, and the whole eleventh article "remissionem peccatorum". The rest of the text, including the formulation of the $4^{\text {th }}$ article which is relevant for our topic, is the same. As a short intermezzo, let us quote (without punctuation marks) side by side the two texts (we highlighted in blue the passages in the text of $\mathrm{R}$ which are omitted in Proto-R):

306 Hahn, Bibliothek der Symbole, 20.

307 Kelly, J. N. D.: Early Christian Creeds ( $3^{\text {rd }}$ edition 1972). Continuum, London - New York (reprint) 2008. 119. (hereafter Kelly, J. N. D.: Early Christian Creeds. Continuum, London - New York 2008.)

308 Kelly, J. N. D.: Early Christian Creeds. Continuum, London - New York 2008. 130.

309 Westra, Liuwe: The Apostles' Creed. Brepols, Turnhout 2002. 65-68. Inasmuch the problem of Proto- $\mathrm{R}$ and $\mathrm{R}$ from the viewpoint of the $4^{\text {th }}$ article is not relevant we will put aside the detailed analysis of this question.

310 Westra, Liuwe: The Apostles' Creed. Brepols, Turnhout 2002. 27 (R) and 68 (Proto-R).

311 I'm aware that Kelly uses a three-article partitioning for $\mathrm{R}$ and a twelve-article partitioning for $\mathrm{T}$; I, however, will use the twelve-article partitioning for $\mathrm{R}$ as well, due to its close relationship and similar structure with $\mathrm{T}$. 


\section{Proto- $R$}

Credo in deum patrem omnipotentem

Et in Christum Iesum filium eius

Qui natus est de Spiritu Sancto et Maria uirgine

Qui sub Pontio Pilato crucifixus est et sepultus

Tertia die resurrexit

Ascendit in caelos

Sedet ad dexteram Patris

Unde uenturus est iudicare uiuos et mortuos

Et in Spiritum Sanctum

Sanctam ecclesiam

Carnis resurrectionem

\section{$\boldsymbol{R}$}

Credo in deum patrem omnipotentem

Et in Christum Iesum filium eius unicum

dominum nostrum

Qui natus est de Spiritu Sancto et Maria uirgine

Qui sub Pontio Pilato crucifixus est et

sepultus

Tertia die resurrexit a mortuis

Ascendit in caelos

Sedet ad dexteram Patris

Unde uenturus est iudicare uiuos et mortuos

Et in Spiritum Sanctum

Sanctam ecclesiam

Remissionem peccatorum

Carnis resurrectionem

Inasmuch this Creed has both a Greek and Latin version, it seems more likely that its history goes back to the $2^{\text {nd }}$ century when - as we quoted above the statement of Kelly - both languages were used in the Church of Rome.

Henceforth, we will move on to the analysis of the $4^{\text {th }}$ article of Proto-R/R. The Latin text speaks of the Passion of the Lord with the following words: "Qui sub Pontio Pilato crucifixus est et sepultus". The Greek text expresses the same content with some

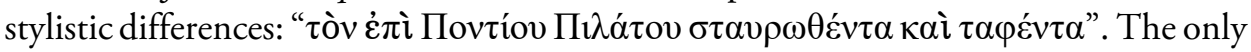
non-theological difference between the Greek and Latin text of this article is that the Latin text expresses with the nominative case of the relative pronoun what the Greek text describes with the accusative of the definite article, which can often suggest the role of the relative pronoun.

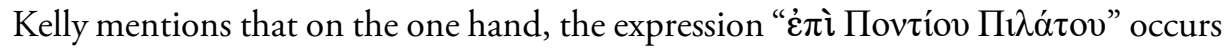
in 1 Tim 6,13 , but on the other hand, it has no place in the earliest summaries of the kerygma. ${ }^{312}$ I would like to expand this information with the following facts: from the 55 occurrences of the name of Pontius Pilatus in the New Testament, 51 can be found in the Gospels, 3 in the Acts and one in the above-mentioned passage of the Pauline letters. Most of these occurrences are related to the trial and crucifixion of Jesus. Out of the four references outside of the Gospels, only one could be counted as a negative

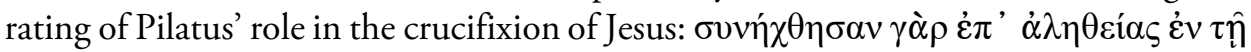

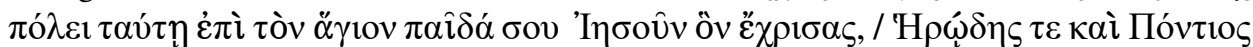

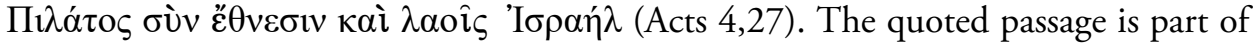
a prayer which was said by the first Christian congregation after releasing Peter and John. It mentions the name of Pilatus as an accomplice of Herod and the religious elite

312 Kelly, J. N. D.: Early Christian Creeds. Continuum, London - New York 2008. 149. 
of the Jews in the betrayal of Jesus. Another passage, namely Acts 3,13, which is a part of Peter's sermon to the people of Israel after the healing of the crippled man, evaluates the role of Pilatus in a rather positive way: Israel denied Jesus in the presence of Pilatus,

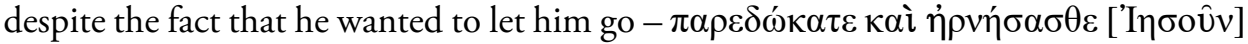

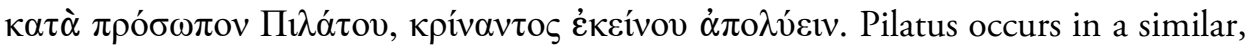
nonetheless rather neutral context in Acts 13,28, where Paul underlines that the leaders of the Jews demanded Pilatus to crucify Jesus in his sermon performed in the synagogue of Antioch in Pisidia. In 1Tim 6,13 Pilatus is mentioned in a completely neutral context: the good confession is emphasized, witnessed by Jesus in front of Pilatus. These four references show that the apostolic kerygma alluded to Pilatus in various contexts. The New Testament kerugma does not seem to lay the burden of the crucifixion on the back of the Roman governor.

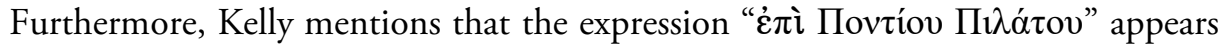
also in the writings of the earliest post-apostolic writers: Ignatius, Justin, Irenaeus and Tertullianus. He argues - and it seems likely to me - that despite the fact that some of the references from their writings have an undeniable anti-heretic (more precisely antiDocetic) context, ${ }^{313}$ the primary reason for taking the reference to Pilatus in the Creed was one more constructive and contextual: "the real explanation of the presence of Pontius Pilate in the creed lies [...] in the fact that the saving story of which the creed is a recapitulation is rooted in history". ${ }^{314}$ Kelly mentions also that although the final form of the reference to Pilatus which became usual in creeds was the expression "sub

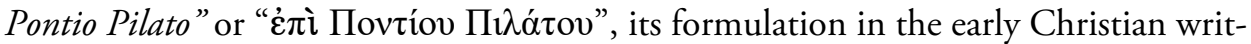
ings may vary: “in the times of Pontius Pilate” (Ignatius' Letter in Smyrna 1), or "under Pontius Pilate, who was governor in Judea” (Justinus, Apologia I,13). ${ }^{315}$

According to Kelly, "the claims of the remaining elements in this section to belong to the apostolic kerygma are undisputed". ${ }^{316}$ That implicitly means that the reference to the crucifixion and redemptive death of Jesus Christ are the most pristine elements of the Christological kerygma of the apostles. By first reading of $\mathrm{R}$, it is eye-catching that after mentioning the crucifixion of Jesus, it omits his death and shifts directly to his burial: "crucifixus est et sepultus". Kelly refutes the opinion of those who think that the burial of Jesus was inserted in the creed in order to underline the reality of his death - i.e., in an anti-Docetic context. He emphasizes that the burial of Jesus Christ appears already in the creedal passages of the New Testament (1Cor 15,4; Rom 6,4), and therefore "there was no need for an anti-Docetic polemic in the first two or three decades

\footnotetext{
313 That means that in an anti-Docetic context the goal of the reference to Pilatus was to underline the reality of Christ's sufferings.

314 Kelly, J. N. D.: Early Christian Creeds. Continuum, London - New York 2008. 150.

315 Kelly, J. N. D.: Early Christian Creeds. Continuum, London - New York 2008. 150.

316 Kelly, J. N. D.: Early Christian Creeds. Continuum, London - New York 2008. 150.
} 
of the Church's history" ${ }^{317}$ According to his logic, the real background of mentioning Jesus's burial in the creed is that it has a prominent role in the Gospel's narrative and in this manner, it was a necessary prelude of the Resurrection. ${ }^{318}$

Although I agree with Kelly in stating that the elements of the apostolic kerygma which were taken into the creed have a constructive-kerygmatic and contextual-historic background rather than polemical, the formulation of the creedal articles became later an effective instrument in refuting and preventing heresies. Both allusions to Pontius Pilatus and the burial of Jesus could become useful instruments in the toolbox of the Christian tradition to emphasize and prove the historicity and reality of Jesus Christ's redemptive passion and death in contrast with all those heresies which denied it or deemed it to be only a phantasm.

The above presented analysis is the core of which Kelly's argumentation made it obvious that the $4^{\text {th }}$ article of the Creed contains elements which became perpetual parts of the Christian kerygma at the latest in the first half of the $2^{\text {nd }}$ century. Accordingly, it is highly possible to set the date of the formulation of this article of $\mathrm{R}$ in the time of Justin Martyr, i.e., in the first half of the $2^{\text {nd }}$ century.

\section{THE DAUGHTER-CREEDS OF R ON THE REDEMPTIVE SUFFERINGS AND DEATH OF JESUS CHRIST}

In the following section, I shall present the manner of formulation of the $4^{\text {th }}$ article in the different daughter-creeds of R. A very distinctive presentation of these regional creeds can be found in the book entitled The Apostles' Creed ${ }^{319}$ By Liuwe Westra. He presents 38 creedal reconstructions or creedal fragments on more than 100 pages which he considers to be witnesses of regional variants of $\mathrm{R}$. If we count also the witnesses that he omits due to several reasons, the number of the daughter-creeds of $\mathrm{R}$ is somewhat higher. If someone compares the creedal reconstructions published by Westra, they can see that not every creedal fragment contains the $4^{\text {th }}$ article. I mention it merely as a "curiosity" that for example the reconstruction of the creed of Ildefonsus of Toledo from the $7^{\text {th }}$ century as well as the reconstruction of the creed of Nicetas of Remesiana contains nearly the whole text of $\mathrm{R}$, but only the $4^{\text {th }}$ article is missing. Due to practical reasons, I will omit the creedal fragments which do not contain the article concerning the passion and death of the Lord Jesus Christ, and at the same time, I will try to find the ones containing relevant information concerning our topic among the text-variants omitted by Westra. 
Furthermore, we can see that most of the creedal reconstructions which contain the $4^{\text {th }}$ article as well date from the post-chalcedonic period; only $25-30 \%$ of them could be placed in the period between 381-451. These statistical data however are not evidence for a later emergence of the creeds. That could rather mean that after the time of the Ecumenical Councils, the number of regional creeds got an accession. It is also interesting that the earliest daughter-creeds of $\mathrm{R}$ arose from Africa and North-Italia. Therefore, we will begin our presentation with these creeds.

\section{THE DAUGHTER-CREEDS OF R FROM NORTH-ITALIA}

The earliest evidence for the daughter-creeds of R among the North-Italian creedal reconstructions presented by Westra is the creed of the Church of Milan, from the end of the $4^{\text {th }}$ century. The Explanatio symboli of Ambrose of Milan reveals that - but it can be reconstructed only in fractions and from two sermons of Augustine, who was a catechumen of Ambrose. From nearly the same era, from the commentary on the apostles' creed of Rufin, we know the creed of the Church of Aquileia. From the Sermons 57-62 de symbolo of Petrus Chrysologus (died ca. 450) we may get to know the creed of the Church of Ravenna.

$\begin{array}{lll}\begin{array}{ll}\text { Church } \\ \text { Milan }\end{array} & \begin{array}{l}\text { Author } \\ \text { Ambrose: } \\ \text { Augustine: }\end{array} & \begin{array}{l}\text { Formulation } \\ \text { sub ... et sepultus } \\ \text { sub Pontio Pilato crucifixus et sepultus }\end{array} \\ \text { Aquileia } & \text { Rufin: } & \begin{array}{l}\text { Crucifixus sub Pontio Pilato et sepultus } \\ \text { Ravenna }\end{array} \\ \text { Petrus Chrysologus } & \text { qui sub Pontio Pilato crucifixus est et sepultus }\end{array}$

Westra omits the creed formerly attributed to the early $5^{\text {th }}$ century bishop Maximus of Turin because nowadays it is no longer considered genuine. The text of the $4^{\text {th }}$ article in the creed ${ }^{324}$ which was considered to be of the Church of Turin precisely agrees with the formulation of the Creed of Ravenna.

Westra omits also the creed which can be found in the $6^{\text {th }}$ century writer Venantius Fortunatus's Expositio symboli, for the reason that it seems to be an adaptation of the creed of Aquileia, and it is

320 Westra, Liuwe: The Apostles' Creed. Brepols, Turnhout 2002. 188.

321 Westra, Liuwe: The Apostles' Creed. Brepols, Turnhout 2002.195.

322 Westra, Liuwe: The Apostles' Creed. Brepols, Turnhout 2002. 198.; Hahn: Bibliothek der Symbole. 30-32.

323 Westra, Liuwe: The Apostles' Creed. Brepols, Turnhout 2002. 206.; Hahn: Bibliothek der Symbole. 12.

324 Hahn: Bibliothek der Symbole. 11. 
impossible to decide whether the creedal quotations stem from Rufinus's original or flow from Venantius's pen, and if the latter is the case, whether he is quoting the creedal variant of his native town in Northern Italy or that of his bishopric Poitiers. ${ }^{325}$

In spite of this uncertainty concerning its origin, I consider it a relevant variant for our topic, due to its formulation of the $4^{\text {th }}$ article: it mentions only the passion of Jesus Christ "crucifixus sub Pontio Pilato". ${ }^{326}$ Thereafter, it shifts to the harrowing in Hell, omitting the passage about the burial of Jesus.

Among the other creeds omitted by Westra we need to mention two other texts: the creed of Auxentius of Milan and the Symbolum fidei in the appendix to Gregory the Great's registrum epistularum. The former seems to be a doctrinal creed which was submitted by its writer in order to demonstrate his orthodoxy, and Rufin's variant echoes in the formulation of the $4^{\text {th }}$ article: “... et crucifixum sub Pontio Pilato, sepultum, ..." ${ }^{327}$ The latter which was omitted because of the lack of a critical edition shows a close relationship with the creed of Ravenna "et sub Pontio Pilato crucifixus est et sepultus" ${ }^{328}$

As we see from the above-mentioned examples, the common characteristic of the word-usage of the $4^{\text {th }}$ article in these creeds is that each of them follows R. Thus, the elements of this article are: the name of Pontius Pilatus with the preposition "sub", the crucifixion and the burial of Jesus. There are differences between them only in style or grammatical construction, but they do not affect the content or the theological message. Furthermore, we can suppose that the theological significance of the word-usage is the same as in the case of $\mathrm{R}$.

\section{THE AFRICAN DAUGHTER-CREEDS OF R}

Now, we will turn our attention to the creeds of the so-called "Latin Africa", or by its official name, Africa Proconsularis. With a rich Christian tradition and a flourishing theological activity, many famous early Christian bishops operated here on a wide range of actions: Tertullian, Cyprian of Carthage, Augustine of Hippo etc. A strong relationship with the Churches of Italia is undeniable, however, due to its geographical location, other theological influences appeared as well (for example, from the School of Alexandria). The earliest creedal passages from the region can be found in the works of Tertullian, but those are regula fidei formulations rather than creeds. But if we ac-

Westra, Liuwe: The Apostles' Creed. Brepols, Turnhout 2002. 183.

Hahn: Bibliothek der Symbole. 23.

Westra, Liuwe: The Apostles' Creed. Brepols, Turnhout 2002. 181-82.

Westra, Liuwe: The Apostles' Creed. Brepols, Turnhout 2002. 182. 
cept Kelly's position ${ }^{329}$, who argues that the regula fidei is like a forerunner of the baptismal creeds, we could take into account their formulations too.

The most important creedal reconstructions from Africa Proconsularis presented in the book of Westra are: the creed of Cyprian of Carthage from his epistula 69-70,330 the creed of Augustine of Hippo from his sermo 215 de symbolo; the creed of Quodvultdeus of Carthage from his three sermons de symbolo and adverus Iudaeos paganos et Arrianos; and the creed of Fulgentius of Ruspe from his contra Fabianum. In the three utilizable creeds we find the following formulations of the $4^{\text {th }}$ article:

Author

Augustine of Hippo

Quodvultdeus of Carthage

Fulgentius of Ruspe
Formulation

crucifixum sub Pontio Pilato et sepultum ${ }^{331}$ crucifixum sub Pontio Pilato et sepultum ${ }^{332}$ crucifixum quoque dicimus et sepultum ${ }^{33}$

The core-elements of the above-mentioned creeds are, just like in $\mathrm{R}$ and its North Italian daughter-creed, the crucifixion and the burial of Jesus, and with the exception of the creed of Fulgentius, the expression "Pontio Pilato".

Other creedal texts omitted by Westra show different formulations. The regula fidei of Tertullian ${ }^{334}$ mentions only the crucifixion under Pontius Pilatus, and by omitting the scene of burial, it shifts to the resurrection. The creed of the $6^{\text {th }}$ century bishop Facundus of Hermianae $e^{335}$ is omitted by Westra because he considers it rather a mixture of $\mathrm{R}$ and the Nicaeno-Constantinopolitan Creed, which uses the same formulation of the $4^{\text {th }}$ article as the creed of Petrus Chrysologus of Ravenna: qui sub Pontio Pilato crucifixus est et sepultus. ${ }^{336}$

329 Kelly, J. N. D.: Early Christian Creeds. Continuum, London - New York 2008. 94-99. It is not a word-by-word statement of Kelly, but rather a consequence of the logic of his argumentation specified by Westra: Westra, Liuwe: The Apostles' Creed. Brepols, Turnhout 2002. 39.

330 This creed is unfortunately so fragmentary that we can not use it for the analysis of the $4^{\text {th }}$ article.

331 Westra, Liuwe: The Apostles' Creed. Brepols, Turnhout 2002. 168.

332 Westra, Liuwe: The Apostles' Creed. Brepols, Turnhout 2002. 178.

333 Westra, Liuwe: The Apostles' Creed. Brepols, Turnhout 2002. 181.; Hahn: Bibliothek der Symbole. 61.

334 Hahn, Bibliothek der Symbole, 69.

335 Hahn: Bibliothek der Symbole, 63.

336 Westra, Liuwe: The Apostles' Creed. Brepols, Turnhout 2002. 157. 
From the sermones de traditione symboli CCXII-CCXIV of Augustine ${ }^{337}$, it seems likely that the famous bishop of Hippo Regius knew a version of the creed which witnessed the redemptive passion of Jesus Christ as "passus sub Pontio Pilato" too. Hahn hypothesizes that this was the original creed of the Church of Hippo, but according to my hypothesis, it seems to be rather an influence of other regional or personal creed, or simply another individual formulation of the summary of the Christian kerygma.

\section{THE DAUGHTER-CREEDS OF R FROM GALLIA}

Now, we shall turn our attention to the daughter-creeds of $\mathrm{R}$ from Gallia. In the tradition of these Churches, we can find more versions of formulation of the $4^{\text {th }}$ article. We find the following formulations in the reconstruction of Gallic creeds presented by Westra: ${ }^{338}$

\author{
Author \\ Phoebadius of Agen ( $4^{\text {th }}$ century) \\ Caesarius of Arles (bishop 503-542): \\ (the introductory part of his) sermo 9 \\ Caesarius of Arles: (the expository part \\ of his) sermo 9 \\ Pseudo-Augustinian liber testimonium \\ fidei ( $6^{\text {th }}$ century) \\ Collectio Eusebiana: homilia 10 \\ Scarapsus of Pirminius (ca. 700-725)
}

\author{
Formulation \\ passum sub Pontio Pilato crucifixum et \\ mortuum et sepultum ${ }^{339}$ \\ passus est sub Pontio Pilato crucifixus \\ mortuus et sepultus ${ }^{340}$ \\ passus sub Pontio Pilato crucifixus mortuus et \\ sepultus $^{341}$ \\ passus sub Pontio Pilato crucifixus mortuus et \\ sepultus $^{342}$ \\ Crucifixus et sepultus ${ }^{343}$ \\ passus sub Pontio Pilato crucifixus mortuus et \\ sepultus $^{344}$
}

\footnotetext{
337 Hahn: Bibliothek der Symbole. 63. For the text of the mentioned sermons

see: http://www.monumenta.ch/latein/text.php?tabelle=Augustinus\&rumpfid=Augustinus, \%20 Sermones,\%2020,\%20\%20212\&nf $=1$;

http://www.monumenta.ch/latein/text.php?tabelle=Augustinus\&rumpfid=Augustinus, \%20Serm ones, $\% 2020, \% 20 \% 20213 \& n f=1$;

http://www.monumenta.ch/latein/text.php?tabelle=Augustinus\&rumpfid=Augustinus, \%20Serm ones, $\% 2020, \% 20 \% 20214 \& \mathrm{nf}=1$ (all three sermons accessed 05-11-2014.)

338 Unfortunately the earliest Gallic witnesses enumerated by Westra (Salvian of Marseilles, Faustus of Riez, Faustinus) do not contain the $4^{\text {th }}$ article.

339 Hahn: Bibliothek der Symbole. 70.

340 Westra, Liuwe: The Apostles' Creed. Brepols, Turnhout 2002. 123.

341 Westra, Liuwe: The Apostles' Creed. Brepols, Turnhout 2002. 126.

342 Westra, Liuwe: The Apostles' Creed. Brepols, Turnhout 2002. 130.

343 Westra, Liuwe: The Apostles' Creed. Brepols, Turnhout 2002. 136.

344 Westra, Liuwe: The Apostles' Creed. Brepols, Turnhout 2002. 137.
} 


\author{
Author \\ Missale Gallicanum Vetus (ca. 700) \\ Bobbio Missal ( $8^{\text {th }}$ century)
}

\section{Formulation}

passus sub Pontio Pilato crucifixus mortuus et sepultus $^{345}$

Passum sub Pontio Pilato crucifixum mortuum et sepultum ${ }^{346}$

We can see in the table presented above that almost all creeds have an expansion of the $4^{\text {th }}$ article in the Gallic churches. As an exception, we can specify the creed from the homilia 10 of the Collectio Eusebiana (where we read only crucifixus et sepultus), and a creed found in Paris dating from either the sixth or the seventh century, which formulates as "crucifixum sub Pontio Pilato".347

We have to mention that the creed of Gregory of Tours, which - according to Westra - offers a summary of the Christian faith but does not refer to R or T, ${ }^{348}$ does not refer to the passion at all: "Credo in Jesum Christum, Filium ejus unicum, dominum deum nostrum. Credo eum die tertia resurrexisse..."349 The Creed of Victricius of Rotomagum $^{350}$, omitted by Westra for the same reason, enumerates the events of Jesus's life without dating - "passus est, crucifixus, sepultus". In this case, like in all the other creeds in this group, the expression passus est or passus could denote both the passion of Jesus Christ from his birth to his death, and his passion endured concerning the crucifixion.

\section{THE DAUGHTER-CREEDS OF R FROM HISPANIA}

In the creeds from the Iberian-peninsula, we find the following formulation of the $4^{\text {th }}$ article:

\section{Author}

Priscillian of Avila (shortly after 381)

Martinus of Braga: de correctione rusticorum $(573 / 74)$

\section{Formulation}

passum sub Pontio Pilato crucifixum et sepultum ${ }^{351}$

passus sub Pontio Pilato crucifixus et sepultus $s^{352}$

345 Westra, Liuwe: The Apostles' Creed. Brepols, Turnhout 2002. 138.

346 Westra, Liuwe: The Apostles' Creed. Brepols, Turnhout 2002. 139; 141; 142.

347 Hahn, Bibliothek der Symbole, 73-74.

348 Westra, Liuwe: The Apostles' Creed. Brepols, Turnhout 2002. 108.

349 Hahn, Bibliothek der Symbole, 73.

350 Hahn, Bibliothek der Symbole, 70.

351 Westra, Liuwe: The Apostles' Creed. Brepols, Turnhout 2002. 146. The reconstructed text of this creed (inclusive the $4^{\text {th }}$ article) seems to be slightly uncertain.

352 Westra, Liuwe: The Apostles' Creed. Brepols, Turnhout 2002. 147. 


\section{Author}

Mozarabic Missale Mixtum

Mozarabic Liber ordinum episcopalis

Ildefonsus of Toledo (657-667)

An inscription from Toledo (650-700)

Etherius of Osma and Beeatus of Liébana: aduersus Elipandum (after 785)

\section{Formulation}

passus sub Pontio Pilato crucifixus et sepultus $^{353}$

passus sub Pontio Pilato crucifixus et sepultus $^{354}$

sub Pontio Pilato crucifixus et sepultus ${ }^{355}$

... sub Pontio Pilato cru(cifixus) ${ }^{356}$

passus sub Pontio Pilato crucifixus et sepultus $^{357}$

These examples prove that the formulation of the $4^{\text {th }}$ article in the Churches of Hispania show a theoretical relationship with the Gallic creeds, but they expand R only with the expression "passus sub", omitting the addition of "mortuus".

\section{OTHER DAUGHTER-CREEDS OF R}

In the last section we turn our attention to the daughter-creeds of $\mathrm{R}$ which could not be set in the groups presented above. It is unspeakably unfortunate that even the $4^{\text {th }}$ article is missing from the creed of Nicetas of Remesiana, from the Latin Balkan. ${ }^{358}$ From this region - among the variants presented by Westra - we have only a very fragmentary inscription from the Croatian island Kres (Cherso), where there remained the following fragment from the $4^{\text {th }}$ article: "passus sub Pontio Pilato crucifixus". ${ }^{359}$

Another creedal variant can be found in an Irish liturgical manuscript from the end of the $7^{\text {th }}$ century, the so-called Antiphonary of Bangor. It contains a variant of the Apostles Creed, with the following formulation of the $4^{\text {th }}$ article: "passum sub Pontio Pilato qui crucifixus et sepultus". ${ }^{60}$

Furthermore, we have to mention the creed from the Greek-Latin Psaltery of Pope

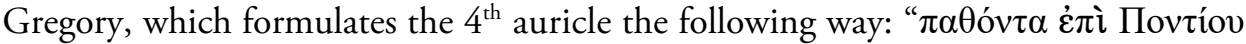

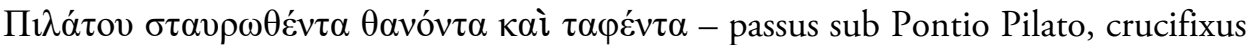
mortuus et sepultus. ${ }^{361 "}$

353 Westra, Liuwe: The Apostles' Creed. Brepols, Turnhout 2002. 148.

354 Westra, Liuwe: The Apostles' Creed. Brepols, Turnhout 2002. 149.

355 Westra, Liuwe: The Apostles' Creed. Brepols, Turnhout 2002. 151. Westra mentions that the text of this article is not quoted by Ildefonsus, but only expounded. Its reconstruction is the suggestion of Kattenbusch.

356 Westra, Liuwe: The Apostles' Creed. Brepols, Turnhout 2002. 154. The text of this inscription is extremely fragmentary.

357 Westra, Liuwe: The Apostles' Creed. Brepols, Turnhout 2002. 153.

358 Westra, Liuwe: The Apostles' Creed. Brepols, Turnhout 2002. 212-16.

359 Westra, Liuwe: The Apostles' Creed. Brepols, Turnhout 2002. 218.

360 Westra, Liuwe: The Apostles' Creed. Brepols, Turnhout 2002. 220.

361 Hahn: Bibliothek der Symbole. 30. 


\section{EXCURSUS: A BRIEF SUMMARY OF THE ORIENTAL LANDSCAPE}

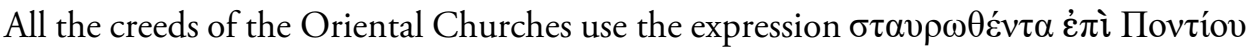
$\Pi \imath \lambda \alpha$ q́ $\tau$ ov or its synonyms in order to express the passion of the Lord. Here we can enumerate the creed of Eusebius of Caesarea, ${ }^{362}$ Cyril of Jerusalem, ${ }^{363}$ Epiphanius of Salamis, ${ }^{364}$ the creeds of the Syrian Churches (Laodicea, Antioch), ${ }^{365}$ the creeds of the Churches from Asia Minor, ${ }^{366}$ the creed of the Nestorians ${ }^{367}$ and the Armenian ${ }^{368}$ and $\mathrm{Copti}^{369}$ creeds. In these creeds, Pilate's name does not occur with the verb $\pi \alpha$ ó $\sigma \omega$ but

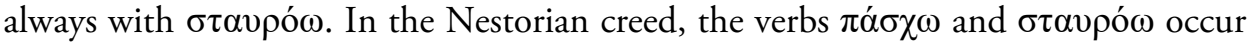
side by side, and the verb $\sigma \tau \alpha v \rho o ́ \omega$ may refer to the events which happened under the procuratorship of Pontius Pilate, and the word $\pi \alpha ́ \sigma \chi \omega$ could denote all sufferings, which the Lord has endured during his life. The Bibliothek der Symbole under $\$ 138$ published an Armenian Creed probably from the second half of the $5^{\text {th }}$ century in which we read: "hernach kam er willig zur Marter, gekreuzigt... - thereafter he was anguished of his own accord, and [he was] crucified." In this creed the expression "zur Marter kam" alludes to the events of Good Friday.

In the West, however, beginning with an occurrence in Augustine's work, in Spain and France we find the consistent addition of 'passus est' before mentioning the crucifixion of Christ. The words 'sub Pilato' are now found between 'passus' and 'crucifixus'. The textual history suggests that it originally qualified the 'crucifixus' rather than the 'passus'.

Finally, let us proceed with the analysis of the passages concerning the passion of the Lord in the Creeds of the Ecumenical Councils. In the Nicene Creed, the word $\pi \alpha$ -

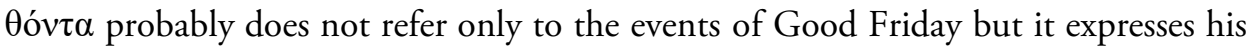
passions in a rather general sense. The text of the so-called Nicaeno-Constantinopolita-

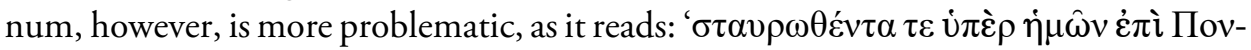

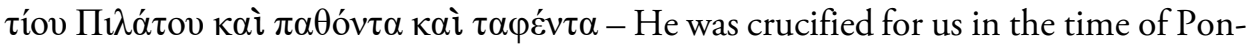
tius Pilate, He suffered and was buried...' The Latin translation omits the verb $\pi \alpha$ $\theta$ óv $\tau \alpha$, and we read the following text: 'crucifixus est pro nobis sub Pontio Pilato, et sepultus est - He was crucified for us in the time of Pontius Pilate, and He was buried...' The Hungarian Ecumenical translation of this Creed renders the meaning of the text with the construction of a 'hidden object': 'He was crucified for us in the time of 
Pontius Pilate, He suffered [death] and was buried...' The fact that the verb $\pi \alpha \sigma \chi \omega$ is used after the verb $\sigma \tau \alpha$ oó $\omega$ suggests that in this situation, ' $\pi \alpha ́ \sigma \chi \omega$ ' has a different meaning: it refers neither to the events from Jesus' birth to his death, nor to the events of Good Friday but rather to the precise moment of His death. The Formula of Reunion accepted after the Council of Ephesus (in 433) does not specify the passion of Jesus Christ, since the main question under debate between the bishops was entirely different.

\section{Closing Thoughts}

From the above presented creedal versions it is obvious - as Liuwe Westra also points it out ${ }^{370}$ - that the intercalation "passus" or "passus est" before "sub Pontio Pilato" is a characteristic of the Gallic and Hispanic Churches. In Gallia - perhaps for the sake of completeness ${ }^{371}$ - the insertion "mortuus" also has been added to the creed. The socalled Apostolic Creed has developed from these Gallic and perhaps Hispanic creeds, which later became accepted (Textus receptus) in the western Christian world as a result of the Carolingian influence ${ }^{372}$. Kelly argues that the adoption of $\mathrm{T}$ by the Roman Church at the critical epoch of the $8^{\text {th }}-10^{\text {th }}$ centuries on the one hand saved "the Roman liturgy for Rome and the Western World", and on the other hand it "was merely handing back to her, enriched and improved, that same venerable rule of faith which she herself had compiled in the second century as a epitome of the everlasting gospel." 373 In the seventh and eighth centuries, this version of the creed became most common in the German Churches and in the ninth and tenth centuries, as a result of the mission of the Franko-German church, on the British Isles as well.

We saw in the introductory presentation that the idea of Jesus's passion as a reference to His whole life was not alien in the Apostolic kerygma. The earliest creedal formulation referred mainly to His crucifixion, death and burial under (i.e., in the time of) Pontius Pilatus. Later-most likely in the last phase of the patristic golden age -there began the apparition of the expansion of the $4^{\text {th }}$ article with the words "passus" and "mortuus". This enlarged article - due to the missing punctuation marks - could be interpreted in a twofold way: on the one hand, as a reference to Jesus's Calvary under Pontius Pilatus, which then was detailed with the words "crucifixus, mortuus et sepultus", while on the other hand, the word passus could denote Jesus's suffering endured during His whole life, the climax of which being his crucifixion, death and burial under Pontius Pilatus.

Westra, Liuwe: The Apostles' Creed. Brepols, Turnhout 2002. 235.

Westra, Liuwe: The Apostles' Creed. Brepols, Turnhout 2002. 235.

Kelly, J. N. D.: Early Christian Creeds. Continuum, London - New York 2008. 411-34.

Kelly, J. N. D.: Early Christian Creeds. Continuum, London - New York 2008. 434. 
The punctuation of the accepted form of the Creed follows the first way of interpretation. But based on the evidence presented in the introductory part, one might say that the creedal formula accepted in the bigger part of Europe ("passus sub Pontio Pilato') is theologically inexact. We saw that the passion of the Lord did not begin with the events of Good Friday, but with His birth. Nevertheless - possibly due to Roman influence after the $10^{\text {th }}$ century -, the Apostolic Creed was accepted in the European area in this form. The other version, which is more accurate in a theological sense, did not become so well-known or accepted in Europe. Yet, if the Creed is (or rather should be) like a map of the Holy Scripture, the more accurate wording is an indispensable necessity.

According to the historical and theological evidence presented above, I recommend the modification of the punctuation in the $4^{\text {th }}$ article of from the Christological passage of the Apostle's Creed in order to follow the other way of interpretation and to recite the Creed in our churches the following way:

"I believe in Jesus Christ, the Only-begotten Son of God, our Lord, who was conceived by the Holy Spirit, born of the Virgin Mary; He suffered; He was crucified under Pontius Pilate, died, and was buried ..."

I deem this correction necessary, since the Apostle's Creed can thus remain in the line of the theologically accurate creeds.

\section{BIBLIOGRAPHY}

Geréb Pál, Barth Károly Dogmatikája, Kolozsvár, Erdélyi Református Egyházkerület, 2006.

Hahn, August (ed.): Bibliothek der Symbole und Glaubensregeln der Alten Kirche. Verlag von E. Morgenstern, Breslau 1897.

Kelly, J. N. D.: Early Christian Creeds ( $3^{\text {rd }}$ edition 1972). Continuum, London - New York (reprint) 2008.

Kirsopp Lake (ed.), The Apostolic Fathers, http://www.ccel.org/ccel/lake/fathers2.html (opened at 20. February 2007.).

Oxford Latin Dictionary, Oxford, Clarendon Press, 1968.

Papp György: The Passion of the Lord Jesus Christ in Early Christian Confessions, in: Református Szemle (Reformed Review), Cluj-Napoca 2008/6. 700-708.

Ravasz László, Kis dogmatika, Budapest, Kálvin Kiadó, 1996.

Robinson, J. A. T.: Redating the New Testament, London, SCM Press LTD, 1976.

Thiede, Carsten Peter Thiede, Aki látta Jézust, Debrecen, Goldbook, s.a.

Thiede, Carsten Peter, Eyewitness to Jesus, Doubleday, 1996.

Westra, Liuwe: The Apostles' Creed. Origin, History, and Some Early Commentaries. Brepols, Turnhout 2002. 